\title{
COULD RED CELL DISTRIBUTION WIDTH SERVE AS A NEW INFLAMMATORY MARKER IN CORONARY ARTERY BYPASS GRAFTING?
}

\author{
Murat Günday ${ }^{1}$, Özgür Çiftçi ${ }^{2}$, Kazım Körez $^{3}$
}

Aim. In our study, we researched whether on-pump and off-pump coronary artery bypass grafting (CABG) differ as regards their effect on postoperative red cell distribution width (RDW). Moreover, we also investigated whether there was a link between the preoperative and postoperative RDW levels and the early adverse events after CABG.

Material and methods. In this study there were 127 consecutive patients who had previously undergone CABG. The patients were divided as group 1 (off-pump, n: 49) and group 2 (on-pump, n: 78). The hemogram and biochemistry panel values were measured a day before the operation, on the first, third and seventh days after it, and in the postoperative first and sixth months.

Results. The statistically significant values detected in the hemogram were as follows: postoperative first day hemoglobin, postoperative first day leukocyte, postoperative first day thrombocyte, postoperative first day C-reactive protein, postoperative third day RDW, postoperative third day leukocyte, postoperative seventh day RDW, postoperative seventh day leukocyte, postoperative first month RDW, and postoperative first month thrombocyte $(p<0,05)$. It was found in multivariate analysis that preoperative RDW is an independent risk factor for plasma used in the postoperative period (odds ratio: $0.552 ; 95 \% \mathrm{Cl}: 0.346-0.879 ; \mathrm{P}=0.012$ ). There was no link between preoperative RDW and other early adverse events in the postoperative period $(p>0,05)$

Conclusion. We found that on-pump CABG increases the RDW levels more in the acute period, when compared with off-pump surgery, but that this effect disappears by the sixth month after the operation. For this reason, RDW can be used as a new inflammatory marker in patients undergoing CABG. Moreover, we observed that there was no clinical link between early adverse events after $C A B G$ and the pre- and postoperative RDW levels.

Russ J Cardiol 2014, 7 (111), Engl.: 5-11

Key words: red cell distribution, bypass, on-pump.

${ }^{1}$ Baskent University Medicine Faculty, Department of Cardiac and Vascular Surgery, Ankara; ${ }^{2}$ Baskent University Medicine Faculty, Department of Cardiology, Ankara; ${ }^{3}$ Selcuk University, Faculty of Science, Department of Statistics, Konya, Turkey.

Corresponding author. Özgür Çiftçi, MD Department of Cardiology, Baskent University Konya Application and Research Center, Hocacihan Mah. Saray Cad. No: 1 Selçuklu / Konya, Turkey. Tel: +9033225706 06, Fax: +903322570637, e-mail: drozgurciftci42@gmail.com

CABG - coronary artery bypass grafting, ICU - intensive care unit, LIMA - left internal mammarian artery, RDW - red cell distribution width

Received April 15, 2014.

Revision received May 08, 2014.

Accepted May 15, 2014.

\section{МОЖЕТ ЛИ РАСПРЕДЕЛЕНИЕ ЭРИТРОЦИТОВ СЛУЖИТЬ В КАЧЕСТВЕ НОВОГО ВОСПАЛИТЕЛЬНОГО МАРКЕРА ПРИ АОРТОКОРОНАРНОМ ШУНТИРОВАНИИ?}

\author{
Murat Günday ${ }^{1}$, Özgür Çiftçi ${ }^{2}$, Kazım Körez ${ }^{3}$
}

Цель. В нашем исследовании мы изучали, могут ли on-pump и off-pump методы при коронарном шунтировании (АКШ), различаться в отношении их влияния на послеоперационную ширину распределения эритроцитов (RDW). Кроме того, мы также исследовали, существует ли связь между предоперационным и послеоперационным уровнями RDW и ранними неблагоприятными событиями после АКШ.

Материал и методы. В этом исследовании было 127 пациентов, которые ранее прошли АКШ. Пациенты были разделены: группа 1 (off-pump, n: 49) и группы 2 (on-pump, n: 78). Значения гемограммы и биохимии крови были измерены в день до операции, на первые, третьи и седьмые сутки после нее и в послеоперационном периоде первого и шестого месяцев.

Результаты. Статистически значимые значения, обнаруженные в гемограмме были следующими: в первый послеоперационный день - гемоглобин, лейкоциты, тромбоциты, С-реактивный белок; третий послеоперационный день RDW, лейкоциты; седьмой послеоперационный день - RDW, лейкоциты, первый послеоперационный месяц - RDW и тромбоциты $(p<0,05)$. Было обнаружено при многофакторном анализе, что предоперационные RDW являются независимым фактором риска для плазмы, используемой в послеоперацион-

\section{Introduction}

The red cell distribution width (RDW) as measured in blood hemogram expresses the heterogeneity in the volumetric dimensions of the erythrocytes. Originally it is used to distinguish types of anemia. However, it has been recently demonstrated that an increase in the RDW values may be associated with heart failure, coronary artery disease or peripheral artery disease [1-4]. Moreover, RDW is believed to be an indicator of inflammation as well, since ном периоде (отношение шансов: 0.552; 95\% Cl: 0.346-0.879; $\mathrm{P}=0,012$ ) Не обнаружено связи между предоперационными RDW и ранними осложнениями в послеоперационном периоде ( $>>0,05)$

Заключение. Мы обнаружили, что on-pump АКШ увеличивает уровни RDW в более в острый период, когда по сравнению с off-pump хирургией, однако этот эффект исчезает к шестому месяцу после операции. По этой причине, RDW может быть использован в качестве новых воспалительных маркеров у пациентов, перенесших АКШ. Кроме того, мы заметили, что не было никакой клинической связи между ранними неблагоприятными событиями после АКШ и пред - и послеоперационном уровнями RDW.

Российский кардиологический журнал 2014, 7 (111), Англ.: 5-11

Ключевые слова: распределение эритроцитов, bypass, on-pump.

${ }^{1}$ Baskent University Medicine Faculty, Department of Cardiac and Vascular Surgery, Анкара; ${ }^{2}$ Baskent University Medicine Faculty, Department of Cardiology, Анкара; 3Selcuk University, Faculty of Science, Department of Statistics, Кония, Турция.

an increase in this value might be a result of oxidative stress on the erythrocytes. RDW deformability may contribute to the impairment of blood flow through the microcirculation. Today, coronary artery bypass grafting $(\mathrm{CABG})$ can be made using either the on-pump or off-pump technique. It is known that on-pump surgery has an inflammatory effect because of hypothermia, the contact of the blood with foreign surfaces outside the body, and laminar flow [5]. On account of this inflammation, many tissues and organ 
systems are adversely affected after CABG. Moreover, it is possible for extracorporeal circulation and hemoseparation to cause coupled mechanical and chemical blood trauma, which influences red cell deformability [6].

In this study, we researched whether on-pump and offpump CABG differ as regards their effect on postoperative RDW. Could RDW serve as a new inflammatory marker in CABG? Moreover, we also investigated whether there was a link between the pre- and postoperative RDW levels and the early adverse events after CABG.

\section{Material and methods}

The prospective study we conducted included 127 consecutive patients. The patients were divided as group 1 (off-pump, 38 men, 11 women, n: 49) and group 2 (on-pump, 55 men, 23 women, n: 78). The exclusion criteria were as follows: infection, malignity, hypo- and hyperthyroidism, chronic renal or hepatic failure, abnormal hemogram, leukocyte or thrombocyte count in the blood, emergencies, patients in cardiogenic shock (preoperative use of high-dose inotropes or of intra-aortic balloon), an ejection fraction of 30 or below as revealed by preoperative echocardiography, coronary endarterectomy, left ventricular aneurysm, mechanical complications of coronary artery disease (post- myocardial ventricular septal defect, rupture of the ventricular free wall), valvular heart disease, and combined operation involving heart valve surgery and CABG.

The hemogram and biochemistry panel values were measured a day before the operation, on the first, third and seventh days following it, and in the postoperative first and sixth months. An Abbott Cell-Dyn 3700 Hematology Analyzer (Abbott Diagnostics, Santa Clara, CA, and ABD) was used to measure the blood counts. In our laboratory, the normal range for RDW values for healthy persons is between $11.6-15.5 \%$. The primary outcome, the combination of adverse events, included such factors as ventilation time, the amount of drainage, the length of stay in the intensive care unit (ICU), the period of hospitalization, the amount of blood transfusion, atrial fibrillation, acute renal failure, pleural effusion, stroke, sternal infection, pulmonary infection, reoperation due to bleeding, mediastinitis, return to the ICU, and in-hospital death.

The study was conducted according to the principles included in the Declaration of Helsinki on Biomedical Research involving Human Subjects. The informed consent of all patients was obtained beforehand.

\section{Results of the analysis of the differences between the two groups as regards the demographic variables}

\begin{tabular}{|c|c|c|c|c|}
\hline \multirow[t]{2}{*}{ VARIABLES } & \multicolumn{2}{|l|}{ GROUPS } & \multirow[t]{2}{*}{$t / M W U$} & \multirow[t]{2}{*}{$p$} \\
\hline & Group 1 & Group 2 & & \\
\hline EurosCORE & $2,70 \pm 2,11$ & $3,98 \pm 2,45$ & $-2,982$ & $0,003^{*}$ \\
\hline Average age (years) & $60,46 \pm 10,19$ & $61,41 \pm 8,39$ & $-0,571$ & 0,569 \\
\hline Height $(\mathrm{cm})$ & $166,72 \pm 9,07$ & $163,89 \pm 9,94$ & 1,604 & 0,111 \\
\hline Weight (kg) & $77,05 \pm 11,39$ & $77,80 \pm 14,32$ & $-0,309$ & 0,758 \\
\hline $\operatorname{BMI}\left(\mathrm{kg} / \mathrm{m}^{2}\right)^{* *}$ & $19,78 \pm 1,83$ & $16,62 \pm 1,55$ & $-0,718$ & 0,472 \\
\hline Systolic blood pressure (mmHg) & $128,33 \pm 11,08$ & $130,09 \pm 11,05$ & $-0,624$ & 0,534 \\
\hline Diastolic blood pressure $(\mathrm{mmHg})$ ** & $75,75 \pm 1,88$ & $75,27 \pm 1,44$ & $-0,048$ & 0,962 \\
\hline Heart rate (beats/minute) & $76,27 \pm 7,80$ & $78 \pm 7,02$ & $-1,012$ & 0,315 \\
\hline $\mathrm{BUN}^{\star *}$ & $18,20 \pm 1,35$ & $17,60 \pm 0,72$ & $-0,300$ & 0,764 \\
\hline Creatine ${ }^{\star *}$ & $0,90 \pm 0,03$ & $0,93 \pm 0,03$ & $-0,397$ & 0,691 \\
\hline Fasting blood glucose $(\mathrm{mg} / \mathrm{dL})$ ** & $116,31 \pm 7,32$ & $128,40 \pm 7,05$ & $-1,898$ & 0,058 \\
\hline Total cholesterol (mg/dL) & $181,56 \pm 39,80$ & $184,36 \pm 42,53$ & $-0,362$ & 0,718 \\
\hline Triglyceride $(\mathrm{mg} / \mathrm{dL})^{* *}$ & $171,31 \pm 15,68$ & $167,60 \pm 10,41$ & $-0,555$ & 0,579 \\
\hline HDL cholesterol (mg/dL) & $38,85 \pm 9,33$ & $39,59 \pm 8,02$ & $-0,465$ & 0,643 \\
\hline LDL cholesterol (mg/dL) & $108,54 \pm 33,22$ & $109,27 \pm 32,86$ & $-0,120$ & 0,905 \\
\hline Uric acid (mg/dL) & $5,31 \pm 1,05$ & $5,24 \pm 1,59$ & 0,242 & 0,809 \\
\hline $\operatorname{CRP}(\mathrm{mg} / \mathrm{dL}){ }^{* *}$ & $5,73 \pm 0,88$ & $8,29 \pm 1,33$ & $-0,845$ & 0,398 \\
\hline $\mathrm{GGT}(\mathrm{U} / \mathrm{L}) * *$ & $33,42 \pm 4,93$ & $42,11 \pm 8,67$ & $-0,818$ & 0,426 \\
\hline Preoperative left ventricular EF (\%) & $60,39 \pm 8,00$ & $61,87 \pm 9,46$ & $-0,711$ & 0,479 \\
\hline
\end{tabular}

* - The variables with statistically significant test results $(\mathrm{p}<0,05) ;{ }^{* *}$ - The demographic variables that are subjected to the Mann Whitney-U test as they do not have normal distribution.

Note: In the variables whose change from one group to the other has been measured by Mann Whitney $U$ test, the mean of ordinal numbers has been used instead of the mean value.

Abbreviations: BMI - body mass index, BUN - blood urea nitrogen, CRP - C-reactive protein, EF - ejection fraction, GGT - Gamma glutamil transpherase, HDL cholesterol - high density lipoprotein, LDL - low density lipoprotein, MWU - Mann Whitney-U test value. 
The differences between the two groups in RDW, MPV, thrombocyte, hemoglobin, leukocyte and CRP values during the preoperative period and on the postoperative first, third, and seventh days as well as in the postoperative first and sixth months

\begin{tabular}{|c|c|c|c|c|}
\hline \multirow[t]{2}{*}{ VARIABLES } & \multicolumn{2}{|l|}{ GROUPS } & \multirow[t]{2}{*}{$t / M W U$} & \multirow[t]{2}{*}{$p$} \\
\hline & Group 1 & Group 2 & & \\
\hline Preop. MPV (fL) ${ }^{* *}$ & $7,74 \pm 0,27$ & $7,94 \pm 0,12$ & $-0,429$ & 0,668 \\
\hline Preop. RDW (\%) & $15,24 \pm 0,36$ & $15,51 \pm 0,13$ & $-0,266$ & 0,790 \\
\hline Preop. leukocyte $(\mathrm{K} / \mu \mathrm{L})$ & $8,53 \pm 3,46$ & $7,69 \pm 1,84$ & 1,565 & 0,122 \\
\hline Preop. thrombocyte $(\mathrm{K} / \mu \mathrm{L})^{* *}$ & $247 \pm 6,64$ & $257,21 \pm 10,24$ & $-0,151$ & 0,790 \\
\hline Preop. $\mathrm{Hb}$ (g/dL) & $13,69 \pm 2,84$ & $13,45 \pm 1,63$ & 0,601 & 0,596 \\
\hline Postop. $1^{\text {st }}$ day MPV (fL) ${ }^{* *}$ & $8,44 \pm 0,17$ & $8,17 \pm 0,21$ & $-1,259$ & 0,208 \\
\hline Postop. $1^{\text {st }}$ day RDW (\%) ${ }^{* *}$ & $15,36 \pm 0,15$ & $15,93 \pm 0,21$ & $-2,023$ & 0,043 \\
\hline Postop. $1^{\text {st }}$ day leukocyte $(K / \mu L)$ & $10,39 \pm 3,71$ & $11,94 \pm 3,75$ & $-2,264$ & 0,025 \\
\hline Postop. $1^{\text {st }}$ day $\mathrm{Hb}(\mathrm{g} / \mathrm{dL})$ & $12,15 \pm 1,59$ & $11,04 \pm 1,34$ & 3,098 & 0,002 \\
\hline Postop. $1^{\text {st }}$ day thrombocyte $(\mathrm{K} / \mu \mathrm{L})$ & $213,45 \pm 51,65$ & $178,25 \pm 75,74$ & 4,189 & 0,000 \\
\hline Postop. $1^{\text {st }}$ day CRP (mg/L) & $133,36 \pm 15,11$ & $99,35 \pm 7,58$ & $-2,471$ & 0,013 \\
\hline Postop. $3^{\text {rd }}$ day RDW (\%) & $15,16 \pm 1,10$ & $16,05 \pm 1,64$ & $-3,373$ & 0,001 \\
\hline Postop. $3^{\text {rd }}$ day leukocyte $(K / \mu L)$ & $8,75 \pm 2,90$ & $10,20 \pm 3,16$ & $-2,588$ & 0,011 \\
\hline Postop. $3^{\text {rd }}$ day Hb (g/dL) & $11,29 \pm 0,17$ & $11,43 \pm 0,28$ & $-0,050$ & 0,960 \\
\hline Postop. $3^{\text {rd }}$ day thrombocyte $(\mathrm{K} / \mu \mathrm{L})$ & $209,94 \pm 44,75$ & $177,17 \pm 78,32$ & $-0,381$ & 0,704 \\
\hline Postop. $3^{\text {rd }}$ day CRP (mg/L) & $148,99 \pm 64,64$ & $130,80 \pm 49,66$ & 1,254 & 0,215 \\
\hline Postop. $7^{\text {th }}$ day MPV (fL) & $7,72 \pm 0,78$ & $7,73 \pm 1,29$ & $-0,013$ & 0,989 \\
\hline Postop. $7^{\text {th }}$ day RDW (\%) & $15,41 \pm 0,22$ & $16,07 \pm 0,19$ & $-2,697$ & 0,007 \\
\hline Postop. $7^{\text {th }}$ day leukocyte $(K / \mu L)$ & $8,39 \pm 2,05$ & $10,13 \pm 2,81$ & $-3,176$ & 0,002 \\
\hline Postop. $7^{\text {th }}$ day $\mathrm{Hb}(\mathrm{g} / \mathrm{dL})^{* *}$ & $11,78 \pm 0,17$ & $12,33 \pm 0,34$ & $-0,811$ & 0,418 \\
\hline Postop. $7^{\text {th }}$ day thrombocyte $(\mathrm{K} / \mu \mathrm{L})$ & $281,58 \pm 61,69$ & $273,11 \pm 97,79$ & $-1,083$ & 0,281 \\
\hline Postop. $7^{\text {th }}$ day CRP $(\mathrm{mg} / \mathrm{L})$ & $63,51 \pm 24,65$ & $65,16 \pm 26,76$ & $-0,289$ & 0,773 \\
\hline Postop. $1^{\text {st }}$ month MPV (fL) & $7,47 \pm 0,95$ & $7,26 \pm 0,90$ & 1,167 & 0,246 \\
\hline Postop. $1^{\text {st }}$ month $\mathrm{Hb}(\mathrm{g} / \mathrm{dL})$ & $13,42 \pm 1,02$ & $12,99 \pm 1,15$ & $-0,139$ & 0,890 \\
\hline Postop. $1^{\text {st }}$ month thrombocyte $(K / \mu L)$ & $339,35 \pm 86,62$ & $341,87 \pm 97,63$ & 1,997 & 0,048 \\
\hline Postop. $1^{\text {st }}$ month CRP (mg/L) & $16,24 \pm 3,21$ & $23,46 \pm 4,67$ & $-0,285$ & 0,776 \\
\hline Postop. $6^{\text {th }}$ month MPV (fL) & $8,12 \pm 1,43$ & $7,94 \pm 1,22$ & 0,647 & 0,519 \\
\hline Postop. $6^{\text {th }}$ month RDW (\%) & $16,26 \pm 1,11$ & $16,63 \pm 1,47$ & $-1,291$ & 0,200 \\
\hline Postop. $6^{\text {th }}$ month leukocyte $(\mathrm{K} / \mu \mathrm{L})$ & $7,30 \pm 1,63$ & $7,86 \pm 2,24$ & $-1,413$ & 0,161 \\
\hline Postop. $6^{\text {th }}$ month thrombocyte $(\mathrm{K} / \mu \mathrm{L}){ }^{* *}$ & $259 \pm 11,01$ & $261,07 \pm 11,46$ & $-0,310$ & 0,757 \\
\hline Postop. $6^{\text {th }}$ month $\mathrm{Hb}(\mathrm{g} / \mathrm{dL})$ & $14,68 \pm 1,32$ & $14,18 \pm 1,28$ & 1,839 & 0,069 \\
\hline Postop. $6^{\text {th }}$ month CRP $(\mathrm{mg} / \mathrm{L}){ }^{* *}$ & $4,79 \pm 1,40$ & $12,85 \pm 3,74$ & $-0,460$ & 0,646 \\
\hline
\end{tabular}

" - The variables with statistically significant test results $(p<0,05) ;{ }^{* *}$ - The demographic variables that are subjected to the Mann Whitney-U test as they do not have normal distribution.

Note: In the variables whose change from one group to the other has been measured by Mann Whitney $U$ test, the mean of ordinal numbers has been used instead of the mean value.

Abbreviations: CRP - C-reactive protein, $\mathrm{Hb}$ - Haemoglobin, MPV - Mean platelet volume, Preop. - Preoperative, Postop.—Postoperative, RDW - Red cell distribution width.

\section{Cardiac Surgery}

On-pump surgery: Median sternotomy was applied to each patient under anesthesia. Standard aorta-caval cannulation was used, along with a membrane oxygenator and a roller pump. The patients were routinely cooled off to $28-30^{\circ} \mathrm{C}$. The arterial and venous grafts were made ready. For the protection of the myocardium, a cold crystalloid cardioplegia was used. It was administered every 20 minutes. The anastomoses were first applied to the right coronary artery or its posterior descending branch, then to the circumflex coronary artery branches, afterwards to the diagonal artery, and finally to the left anterior descending (LAD) coronary artery. The left internal mammarian artery (LIMA) was routinely 
Table 3

\section{Operative and postoperative data}

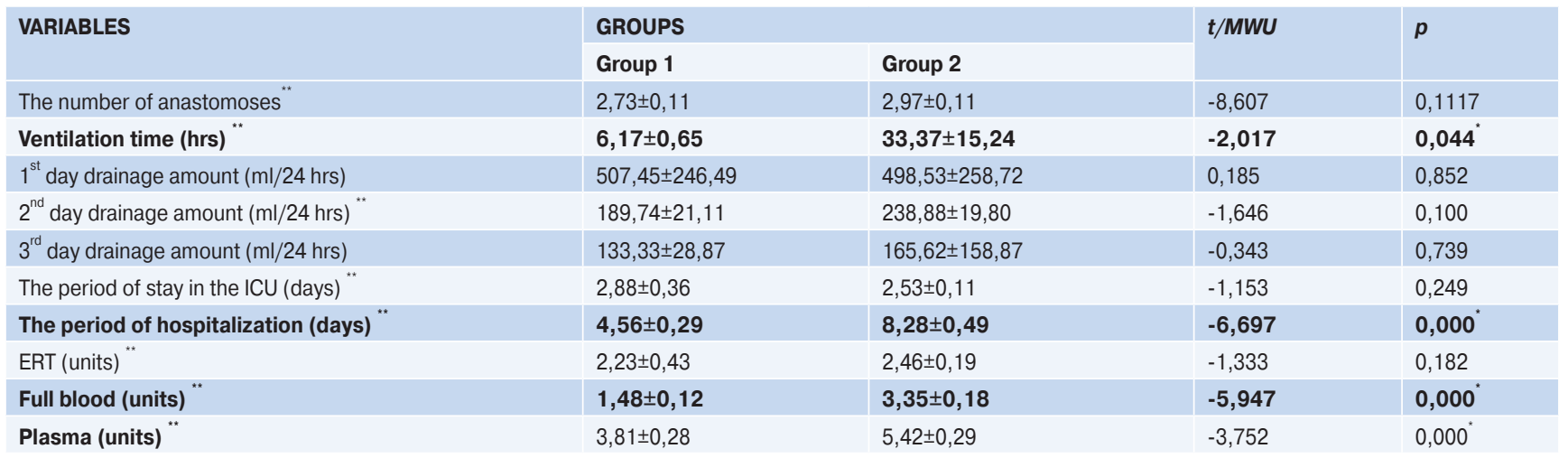

* - The variables with statistically significant test results $(p<0,05) ;{ }^{*}$ - The demographic variables that are subjected to the Mann Whitney-U test as they do not have normal distribution.

Note: In the variables whose change from one group to the other has been measured by Mann Whitney $U$ test, the mean of ordinal numbers has been used instead of the mean value.

Abbreviations: ERT - erythrocyte suspension, hrs - hours.

Table 4 Off-pump surgery: The chest was opened using median

Postoperative early adverse events

\begin{tabular}{|c|c|c|c|c|}
\hline \multirow{2}{*}{ VARIABLES } & \multicolumn{2}{|c|}{ GROUPS } & \multirow{2}{*}{$x$} & \multirow{2}{*}{$p$} \\
\hline & Group 1 & Group 2 & & \\
\hline $\begin{array}{l}\text { AF } \\
0 \\
1\end{array}$ & $\begin{array}{l}44 \\
5\end{array}$ & $\begin{array}{l}60 \\
14\end{array}$ & 1,714 & 0,214 \\
\hline $\begin{array}{l}\text { Pleural effusion } \\
0 \\
1\end{array}$ & $\begin{array}{l}49 \\
0\end{array}$ & $\begin{array}{l}64 \\
10\end{array}$ & 7,208 & $0,006^{*}$ \\
\hline $\begin{array}{l}\text { ARF } \\
0 \\
1\end{array}$ & $\begin{array}{l}48 \\
1\end{array}$ & $\begin{array}{l}73 \\
1\end{array}$ & 0,088 & 1,000 \\
\hline $\begin{array}{l}\text { Sternal infection } \\
0 \\
1\end{array}$ & $\begin{array}{l}49 \\
0\end{array}$ & $\begin{array}{l}70 \\
4\end{array}$ & 2,738 & 0,150 \\
\hline $\begin{array}{l}\text { Pulmonary infection } \\
0 \\
1\end{array}$ & $\begin{array}{l}48 \\
1\end{array}$ & $\begin{array}{l}71 \\
3\end{array}$ & 0,380 & 1,000 \\
\hline $\begin{array}{l}\text { Reoperation due to bleeding } \\
0 \\
1\end{array}$ & $\begin{array}{l}49 \\
0\end{array}$ & $\begin{array}{l}73 \\
1\end{array}$ & 0,668 & 1,000 \\
\hline $\begin{array}{l}\text { Mediastinitis } \\
0 \\
1\end{array}$ & $\begin{array}{l}49 \\
0\end{array}$ & $\begin{array}{l}73 \\
2\end{array}$ & 1,328 & 0,518 \\
\hline $\begin{array}{l}\text { Return to the ICU } \\
0\end{array}$ & $\begin{array}{l}49 \\
0\end{array}$ & $\begin{array}{l}73 \\
5\end{array}$ & 3,270 & 0,156 \\
\hline
\end{tabular}

* - The variables with statistically significant test results $(p<0,05)$.

Note: Since the values in the cells turned out to be 5 or less in the observed frequencies, the results of Fisher's Exact test were used when determining whether there was a correlation between the variables.

Abbreviations: AF - atrial fibrillation, ARF - acute renal failure, ERT - erythrocyte suspension, ICU - intensive care unit.

extracted to use for the LAD artery anastomosis. The proximal anastomoses were applied to the aorta under a side clamp. sternotomy. The arterial and venous grafts were made ready. The heart was suspended with pericardial sutures. Then, Octopus Tissue Stabilizers (Medtronic) were used to immobilize the location where distal anastomosis was going to be applied. In those cases that necessitated the anastomoses to be applied to the rear side of the heart, a starfish (Medtronic) was used to position the heart. Following arteriotomy, a coronary shunt (Medtronic) appropriate for the coronary diameter was fitted. The distal and proximal anastomoses were applied as described above. The pericardium was not closed in any of the patients (on-pump or off-pump).

Statistical analysis. We divided all the variables in the study into two groups, on-pump and off-pump, and examined whether there was any difference between these groups as regards the variables in question. For this examination, the Kolmogorov-Smirnov normality test was used to determine whether the variables to be used in the analyses had normal distribution. When testing the differences between the groups, the Independent Samples $\mathrm{T}$ Test (Student $\mathrm{t}$ test) was used for the variables with normal distribution, and Mann Whitney-U test, a nonparametric test, was used for those variables without normal distribution. A significance level of 5\% was taken into account during the evaluation of the analyses. On the other hand, the Chi-square test was used when examining the association of our dependent variable (i.e. whether the group had undergone on-pump or off-pump surgery) with the categorical variables. Since the values observed in the Chi-square test were less than or equal to 5 , the results of Fisher's exact test were evaluated. In the second part of our analyses, we used Logistic Regression Analysis to determine which variables affected RDW and which do not. We selected the variables in the Logistic Regression 
The results of multiple Logistic Regression Analysis for the dependent variable: preoperative RDW

Table 5

\begin{tabular}{|c|c|c|c|c|c|c|}
\hline \multirow[t]{2}{*}{ VARIABLES } & \multicolumn{3}{|c|}{ Univariate Analysis } & \multicolumn{3}{|c|}{ Multivariate Analysis } \\
\hline & $O R$ & $95 \% \mathrm{Cl}$ & $p$ & $O R$ & $95 \% \mathrm{Cl}$ & $p$ \\
\hline Full blood (units) & 0,895 & $0,698-1,147$ & 0,379 & & & \\
\hline Plasma (units) & 0,918 & $0,789-1,070$ & 0,274 & 0,552 & $0,346-0,879$ & $0,012^{*}$ \\
\hline $\mathrm{AF}$ & 1,256 & $0,470-3,353$ & 0,649 & 8,105 & $0,764-86,016$ & 0,083 \\
\hline Pleural effusion & 0,889 & $0,238-3,325$ & 0,861 & & & \\
\hline Sternal infection & 0,438 & $0,044-4,334$ & 0,480 & & & \\
\hline Pulmonary infection & 0,438 & $0,044-4,334$ & 0,480 & & & \\
\hline Return to the ICU & 5,680 & $0,616-52,349$ & 0,125 & & & \\
\hline Ventilation time (hrs) & 0,999 & $0,995-1,003$ & 0,685 & & & \\
\hline 1st day drainage amount (ml/24 hrs) & 1,000 & $0,999-1,002$ & 0,716 & & & \\
\hline 2 nd day drainage amount ( $\mathrm{ml} / 24 \mathrm{hrs}$ ) & 0,999 & $0,996-1,002$ & 0,525 & 1,006 & $0,999-1,012$ & 0,090 \\
\hline ERT (units) & 0,945 & $0,657-1,359$ & 0,760 & & & \\
\hline
\end{tabular}

- The variables with statistically significant test results $(p<0,05)$.

Abbreviations: AF — atrial fibrillation, $\mathrm{Cl}$ - confidence interval, ERT - erythrocyte suspension, hrs - hours, ICU — intensive care unit, OR - odds ratio.

The results of multiple Logistic Regression Analysis for the dependent variable: first month RDW

Table 6

\begin{tabular}{|c|c|c|c|c|c|c|}
\hline \multirow{2}{*}{ VARIABLES } & \multicolumn{3}{|c|}{ Univariate Analysis } & \multicolumn{3}{|c|}{ Multivariate Analysis } \\
\hline & OR & $95 \% \mathrm{Cl}$ & $p$ & $O R$ & $95 \% \mathrm{Cl}$ & $p$ \\
\hline Full blood (units) & 1,099 & $0,818-1,476$ & 0,533 & 0,234 & $0,060-0,914$ & $0,037^{*}$ \\
\hline Plasma (units) & 1,092 & $0,922-1,293$ & 0,310 & 2,257 & $1,004-5,078$ & $0,049^{*}$ \\
\hline $\mathrm{AF}$ & 9,250 & $1,166-73,364$ & $0,035^{*}$ & & & \\
\hline Pleural effusion & 1,687 & $0,324-8,801$ & 0,535 & & & \\
\hline Sternal infection & 1,657 & $0,166-16,500$ & 0,667 & & & \\
\hline Return to the ICU & 2,114 & $0,228-19,608$ & 0,510 & & & \\
\hline Ventilation time (hrs) & 1,000 & $0,995-1,004$ & 0,869 & & & \\
\hline $1^{\text {st }}$ day drainage amount ( $\left.\mathrm{ml} / 24 \mathrm{hrs}\right)$ & 1,000 & $0,999-1,002$ & 0,765 & 1,011 & $1,001-1,020$ & $0,026^{*}$ \\
\hline $2^{\text {nd }}$ day drainage amount ( $\left.\mathrm{ml} / 24 \mathrm{hrs}\right)$ & 0,999 & $0,996-1,002$ & 0,696 & 0,988 & $0,976-1,001$ & 0,066 \\
\hline ERT (units) & 1,288 & $0,799-2,077$ & 0,299 & 0,215 & $0,045-1,019$ & 0,053 \\
\hline
\end{tabular}

" - The variables with statistically significant test results $(p<0,05)$.

Abbreviations: $\mathrm{OR}$ - odds ratio, $\mathrm{Cl}$ - confidence interval, AF — atrial fibrillation, ICU — intensive care unit, ERT - erythrocyte suspension, hrs - hours.

Analysis through the backward selection method. Taking the first and last (eighth) steps in the eight-step results, according to the backward selection method, we determined the variables affecting the dependent variable. In the model containing all the variables, and finally among the variables obtained through the backward method, we determined the variables affecting the RDW value. Since the RDW values were the results of measurements made at six different points in time, we applied logistic regression for every subgroup, while we did not include those models in which none the variables had any effect. The statistics program IBM SPSS 21 was used to calculate all the statistical results.

\section{Results}

The average age was $60.46 \pm 10.19$ in group 1 and $61.41 \pm 8.39$ in group 2. We did not need to use intraaortic balloon pump and/or high-dose inotropes in any of our patients, as would be necessitated by low postoperative ventricular performance. In-hospital mortality (the first 30 days) was not encountered either. Demographically, there was no difference between the two groups with the exception of EuroSCORE (Table 1). The statistically significant values detected in the hemogram were as follows: postoperative first day hemoglobin, postoperative first day leukocyte, postoperative first day thrombocyte, postoperative first day C-reactive protein, postoperative third day RDW, postoperative third day leukocyte, postoperative seventh day RDW, postoperative seventh day leukocyte, postoperative first month RDW, and postoperative first month thrombocyte $(\mathrm{p}<0.05)$ (Table 2$)$.

Examining the operative and postoperative data, a statistically significant difference was detected between the two groups as regards the ventilation time, the period of hospitalization, and the use of full blood and plasma 
$(\mathrm{p}<0.05)$ (Table 3). As for the adverse events in the early postoperative period, a significant difference in pleural effusion was detected between the two groups $(p<0.05)$ (Table 4). It was found in multivariate analysis that preoperative $\mathrm{RDW}$ is an independent risk factor for plasma used in the postoperative period (odds ratio: 0,$552 ; 95 \%$ CI: $0,346-0,879 ; \mathrm{P}=0,012$ ). There was no association between preoperative RDW and other early adverse events in the postoperative period (Table 5).

It was found that postoperative first month RDW constitutes an independent risk factor for full blood used in the postoperative period (odds ratio: 0,$234 ; 95 \% \mathrm{CI}$ : 0,060-0,914; $\mathrm{P}=0,037$ ), plasma (odds ratio: 2,$257 ; 95 \%$ CI: $1.004-5.078 ; \mathrm{P}=0,049)$ and postoperative first day drainage (odds ratio: 1,011; 95\% CI: 1,001-1,020; $\mathrm{P}=0,026)$. It was not associated with any other early adverse events (Table 6). Moreover, no significant correlation was found between postoperative early adverse events and any of the RDW values on the first, third and seventh days and in the sixth month $(p>0,05)$.

\section{Discussion}

To our knowledge, this study shows for the first time in the literature that the RDW levels of the patients undergoing on-pump surgery increase more in the early postoperative period, compared with the RDW levels of the off-pump patients, and that this difference in the respective effects of the two techniques diminishes by the sixth month after the operation. We believe that the reason for this is the triggering effect of cardiopulmonary bypass on inflammation. In addition, the study revealed that there was no statistically significant difference between the two groups as regards early adverse events, and that there was no clinical link in the correlation analysis between the pre- and postoperative RDW levels on the one hand, and early adverse events following surgery on the other.

It is possible to observe elevated RDW levels in many clinical settings including hemolysis, blood transfusions and ineffective red cell production due to the deficiency of iron, vitamin B12 or folate. RDW levels may also rise in such clinical states as pregnancy, thrombotic thrombocytopenic purpura and inflammatory bowel diseases. However, its use in the clinic is generally neglected [7]. Various studies have revealed that high RDW values may lead to an increase in adverse cardiovascular events and even mortality in people with heart failure or coronary artery disease $[1,2]$.

Although the mechanisms that underlie this link remain unclear, it is possible that red blood cell (RBC) deformability has a contributing effect. There is a link between greater variation in RBC volumes (increased $\mathrm{RDW}$ ) and decreased RBC deformability, which can lead to impairment of blood flow through the microcirculation [8]. (The mechanism underlying this phenomenon is not fully known. It is thought that high RDW levels possibly impair the microcirculation). It has been found that increased RDW values are associated with some inflammatory markers $[9,10]$. It has also been shown to be linked with arterial and venous thrombosis, an association that might stem from increased inflammation [11, 12].

In the literature, there are few studies on the link between CABG and RDW. The preoperative RDW has been found to be associated with atrial fibrillation beginning after CABG [13]. Another study has revealed that the RDW constitutes a significant factor that determines the ratio of in-hospital mortality and longterm survival in patients undergoing isolated CABG [14]. In their study, Ertekin Utku Unal et al. showed that there is an association between higher RDW values and early adverse events following CABG surgery [15]. Another study has found an independent association between elevated RDW and recourse to CABG. [16]. In almost all of the studies above on RDW and CABG, the RDW values used have been obtained in the preoperative period only, while no such values are present that pertain to the period after surgery.

There is a link between CABG surgery and systemic inflammation. The activation of neutrophils constitutes a crucial step in inflammation, and leads to neutrophil sequestration within the tissues. Among the potential advantages of off-pump CABG surgery is that it allows for the attenuation of the systemic inflammatory response [17]. In another study, coronary revascularization with cardiopulmonary bypass (CPB) led to a significantly higher level of TNF-alpha, which was linked with P-selectin and ICAM-1 expression. This was accompanied by a requirement for higher catecholamine in the CPB group during the early postoperative period. Although the surgical trauma involved in on-pump and off-pump surgery is comparable, the off-pump technique, dispensing with $\mathrm{CPB}$ and cardioplegic arrest, allows for a significant reduction in systemic and cardiac adhesion molecule expression as well as in catecholamine requirement [18].

We did not encounter any previous studies on the effects of on-pump and off-pump CABG on RDW. In this study we found that on-pump CABG increases the RDW levels more in the acute period, compared with off-pump surgery, but that this effect disappears by the sixth month after the operation. We believe that the reason for this is the triggering effect of cardiopulmonary bypass on inflammation. Moreover, we observed that there was no clinical link between early adverse events after CABG and the pre- and postoperative RDW levels.

\section{Conclusion}

Many previous studies using the basic inflammatory markers have shown that off-pump bypass surgery prevents the secondary inflammatory response that develops after on-pump bypass surgery [19-21]. In our own study, we have found that RDW can be used as a new inflammatory 
marker in patients who have undergone CABG. Determining RDW is easy and brings no extra costs as it is measured in many health centres as part of the routine hemogram examination. According to the results of our study, it can be used as a new inflammatory marker in patients who have undergone CABG. We believe that on this subject there is a need for further prospective, doubleblinded and randomized studies with a larger number of patients.

\section{References}

1. Felker GM, Allen LA, Pocock SJ, et al. Red cell distribution width as a novel prognostic marker in heart failure: data from the CHARM Program and the Duke Databank. J Am Coll Cardiol. 2007:50: 40-7.

2. Tonelli M, Sacks F, Arnold M, et al. Relation Between Red Blood Cell Distribution Width and Cardiovascular Event Rate in People With Coronary Disease. Circulation. 2008;117: 163-8.

3. Ye Z, Smith C, Kullo IJ. Usefulness of red cell distribution width to predict mortality in patients with peripheral artery disease. Am J Cardiol. 2011;107: 1241-5.

4. Pascual-Figal DA, Bonaque JC, Redondo B, et al. Red blood cell distribution width predicts long-term outcome regardless of anaemia status in acute heart failure patients. Eur $\mathrm{J}$ Heart Fail. 2009;11: 840-6.

5. Larmann J, Theilmeier G. Inflammatory response to cardiac surgery: cardiopulmonary bypass versus non-cardiopulmonary bypass surgery. Best Pract Res Clin Anaesthesiol. 2004; $18: 425-38$

6. Lohrer RM, Trammer AR, Dietrich W, et al. The influence of extracorporeal circulation and hemoseparation on red cell deformability and membrane proteins in coronary artery disease. J Thorac Cardiovasc Surg. 1990;99: 735-40.

7. Uyarel H, Isik T, Ayhan E, Ergelen M. Red cell distrubition width (RDW): a novel risk factor for cardiovascular disease. Int J Cardiol. 2012;154: 351-2

8. Patel KV, Mohanty JG, Kanapuru B, et al. Association of the red cell distribution width with red blood cell deformability. Adv Exp Med Biol. 2013;765: 211-6.

9. Lee WS, Kim TY. Relation between red blood cell distribution width and inflammatory biomarkers in rheumatoid arthritis. Arch Pathol Lab Med. 2010;134: 505-6.

10. Sanchez-Chaparro MA, Calvo-Bonacho E, González-Quintela A, et al. Higher red blood cell distribution width is associated with the metabolic syndrome: results of the Ibermutuamur CArdiovascular Rlsk assessment study. Diabetes Care. 2010;33: e40.

\section{Study limitations}

This was an inherently retrospective observational study that included only a small number of patients. The clinical significance of RDW was not clear in CABG. This is a preliminary study and needs further randomized or large volume study. Moreover, the changes in RDW should also be examined in surgeries associated with other cardiological pathologies.

11. Montagnana M, Cervellin G, Meschi T, Lippi G. The role of red blood cell distribution width in cardiovascular and thrombotic disorders. Clin Chem Lab Med. 2011;50:635-41.

12. Cay N, Unal $\mathrm{O}$, Kartal MG et al. Increased level of red blood cell distribution width is associated with deep venous thrombosis. Blood Coagul Fibrinolysis. 2013;24: 727-31.

13. Ertaş G, Aydin C, Sönmez O, et al. Red cell distribution width predicts new-onset atrial fibrillation after coronary artery bypass grafting. Scand Cardiovasc J. 2013;47: 132-5.

14. Warwick R, Mediratta N, Shaw M, et al. Red cell distribution width and coronary artery bypass surgery. Eur J Cardiothorac Surg. 2013;43:1165-9.

15. Ünal E.U, Özen A, Kubat E, Sarıtaş A. Red cell distribution width is associated with early adverse events following coronary bypass surgery. Journal-Cardiovascular Surgery. 2013:1; 43-6.

16. Ephrem G, Kanei Y. Elevated red blood cell distribution width is associated with higher recourse to coronary artery bypass gsraft. Cardiology. 2012;123: 135-41.

17. Schulze C, Conrad N, Sch tz A, et al. Reduced expression of systemic proinflammatory cytokines after off-pump versus conventional coronary artery bypass grafting. Thorac Cardiovasc Surg. 2000;48: 364-9.

18. Wildhirt SM, Schulze C, Schulz C, et al. Reduction of systemic and cardiac adhesion molecule expression after off-pump versus conventional coronary artery bypass grafting. Shock. 2001;16 Suppl 1:55-9.

19. Karu I, Taal G, Zilmer K, et al. Inflammatory/oxidative stress during the first week after different types of cardiac surgery. Scand Cardiovasc J. 2010;44: 119-24.

20. Cavalca V, Sisillo E, Veglia F, et al. Isoprostanes and oxidative stress in off-pump and onpump coronary bypass surgery. Ann Thorac Surg. 2006;81: 562-7.

21. Meng QH, Zhu S, Sohn N, et al. Release of cardiac biochemical and inflammatory markers in patients on cardiopulmonary bypass undergoing coronary artery bypass grafting. J Card Surg. 2008;23: 681-7. 